\title{
What Is Mandarin? The Social Project of Language Standardization in Early Republican China
}

\section{JEFFREY WENG}

Scholars who study language often see standard or official languages as oppressive, helping the socially advantaged to entrench themselves as elites. This article questions this view by examining the Chinese case, in which early twentieth-century language reformers attempted to remake their society's language situation to further national integration. Classical Chinese, accessible only to a privileged few, was sidelined in favor of Mandarin, a national standard newly created for the many. This article argues that Mandarin's creation reflected an entirely new vision of society. It draws on archival sources on the design and promulgation of Mandarin from the 1910s to the 1930s to discuss how the way the language was standardized reflected the nature of the imagined future society it was meant to serve. Language reform thus represented a radical rethinking of how society should be organized: linguistic modernity was to be a national modernity, in which all the nation's people would have access to the new official language, and thus increased opportunities for advancement.

Keywords: China, history, language standardization, literature, media, nationalism, social theory, sociolinguistics, sociology of language

$\mathrm{T}$ He artificiality of China's standard language is no secret. Nonetheless, much of social and sociolinguistic theory until now has been devoted to unmasking the artificiality and arbitrariness of standard languages. But the arbitrariness of the Chinese standard was never hidden from public view. This language, which this essay will refer to simply as "Mandarin," was deliberately designed in the early twentieth century to be distinct from any existing spoken vernacular. This new language, though based on the speech of Beijing, was different from it and every other regional or local speech in China, and it was designed to be the standard for the entire polyglot Chinese nation. Whereas Beijing speech was a language of a particular place spoken by a particular group of people, Mandarin was intended to be, within China, the language of all places and no particular place. Thus universalized, Mandarin could facilitate nationwide communication that previously had been stymied by the nation's extensive multilinguality.

The creation of a Chinese standard language, therefore, was a state-led nationbuilding project, meant to mold a motley collection of peoples into a unified national society. But what was to be the nature of this new society? One of the main goals of language reform in China was to create a standard language that was easier to learn and thus more widely accessible. This desire for a more accessible standard language represented a substantial departure from the previous language situation, in which the official

Jeffrey Weng (jeffrey.weng@berkeley.edu) is PhD Candidate in the Department of Sociology at the University of California, Berkeley. 
language-Classical Chinese-was so difficult to learn that access was restricted to a small segment of society. The promulgation of a national standard language in the early twentieth century therefore represented an attempt to extend educational meritocracy from small segment of elites to all of society. I argue that the creation of a new language was intimately connected to the goal of a new social order.

In so arguing, I diverge from the approaches taken in a small but growing body of scholarship in addressing the question of Chinese language reform. Historians in the past few years have been particularly active in this area, reflecting a resurgence of interest in language in China that began in the United States with the landmark works of the linguist and sinologist John DeFrancis (1950, 1984, 1989). David Moser (2016) has offered a fresh overview of how Mandarin came to be China's national language. Recent studies have also addressed the social history of the origins and growth of Mandarin, documenting the experiences of everyday people in their encounter with the new national language in sound, on the screen, and in print (J. Chen 2013b, 2015; Culp 2008). Other historians have discussed the intellectual history behind the vernacular language movement and the promulgation of Mandarin in China before and after 1949 (Kaske 2008; J. Liu 2016; Tam 2016a, 2016b). Among linguists, the study of Mandarin phonology has driven theorybuilding in generative linguistics (Duanmu 2007), while work by sociolinguists has illuminated popular attitudes about language practices in China (C. Li 2004, 2014; Peng 2016). And one cannot overlook the rapid expansion of Sinophone studies and other significant work in comparative literature in the past three decades (Gunn 1991; L. Liu 1995, 2004; Shih 2011; Tsu 2010; G. Zhou 2011).

In contrast, my intervention into the study of language and China specifically addresses, from a sociological point of view, one of the underlying themes in sociolinguistics and the sociology of language: the drive to unmask the arbitrariness of standard languages, as opposed to their purported correctness and superiority. This drive is often rooted in a desire to show how standard languages are effectively tools of elite oppression, deliberately designed to be obscure so as to restrict access to cultural capital through education, and ultimately access to the labor market. While Pierre Bourdieu (1991) may be the most famous exponent of this point of view, he has not been alone: since the first of the essays collected in Language and Symbolic Power was written in the 1970s, much of the empirical and theoretical work on language and society-done by linguists, sociolinguists, linguistic anthropologists, and sociologists-on numerous cases from around the world contain elements of this line of thinking, whether independent of or in dialogue with Bourdieu (Fishman 1972; Haeri 1997; Hasan 1999; Labov 1966, 1972; Lippi-Green 1997; Milroy 2012).

What I seek to show with the Chinese case, however, is that intentionality matters when it comes to standard languages. A vision of a standard language presupposes a vision of society. The creation of Mandarin, therefore, represents a new way of thinking about language: what it is for, what it does, and what kind of society it is supposed to serve. In this paper, I show how the design of a new standard language was a reflection of a desire for a new kind of national community, one unified in part by a standard language that was more accessible by design. I first clarify the term "Mandarin" in the context of the English-language terminology deployed to describe the highly complex language situation of China. I then survey the social-ideological underpinnings of the existing linguistic historiography of Mandarin, particularly from the May Fourth point of view, and then 
detail the eclectic splicing of existing language practices in which language reformers engaged to create a new standard. Finally, I sketch the incipient efforts of the consolidated Nationalist (Guomindang, or GMD) state to spread Mandarin among the Chinese people. I demonstrate how Mandarin, more than just a new language, was a new kind of language, meant to serve a new kind of society.

\section{Defining Mandarin}

What is Mandarin? In this section, I untangle the many referents of this ambiguous English-language term, one that historian Janet Chen (2013a) has argued "obscures" more than it reveals, thus requiring temporal and conceptual disaggregation. I argue that Mandarin, as a national standard, is both diachronically and synchronically discontinuous from other linguistic forms. That is, it is historically distinct from the antecedents from which it was drawn, and it is formally distinct from the other contemporaneous language practices in China at the time of its creation. These distinctions, as I will argue later on in this essay, were deliberately aimed at creating a new language for a new type of society, national in scope and more widely meritocratic in nature.

The English word "Mandarin" originated in the sixteenth century as a borrowing from the Portuguese mandarim. This Portuguese word claims two influences: the Sanskrit term mantri, or "official," and the Portuguese verb mandar, "to command" (Mair 1991, 11-12; Oxford English Dictionary 2000). These references to officialdom and commanding are apt: for the Portuguese of the sixteenth century, the word referred to the spoken language that imperial officials used to communicate with one another during the Ming (1368-1644) and Qing (1644-1911) dynasties, known as guanhua, or "language of the officials."

Over time, however, the English word "Mandarin" has taken on a greater variety of meanings. Linguist and sinologist Robert Sanders (1987), in a plea for terminological specificity, has argued that it has in fact four main referents: (1) "Idealized Mandarin," by which he meant the national standard language; (2) "Imperial Mandarin," by which he meant guanhua; (3) "Geographical Mandarin," by which he meant a family of interrelated dialects spanning China from the northeast to the southwest, which he took to be an analytical construct of linguists; and (4) "Local Mandarin," by which he meant varieties of the language inflected by local usage. By far the most frequently used of these four possibilities is the first: in common usage, "Mandarin" or "Mandarin Chinese" usually refers to China's standard spoken language. In fact, I would argue that this is the predominant meaning of the word, since the other three concepts seem to be subsidiary to the first. That is to say, Imperial Mandarin, Geographical Mandarin, and Local Mandarin are distinct entities insofar as they are not Idealized Mandarin.

Even for this most common usage of Mandarin, the equivalent Chinese terms are too numerous to discuss in their entirety in this article, and they have received sufficient attention elsewhere (Mair 1991, 10-12; Norman 1988, 135-38). For reasons of brevity, I will only highlight some of the more common Chinese equivalents here. In general, the Chinese terms are more restrictive in their meaning than the English term. Guoyu, or "national language," is now the equivalent to "Mandarin" most used in Taiwan, but during the Qing dynasty it referred to the Manchu language (Elliott 2001, 
291; 2006, 37-38); in the early twentieth century, the term was repurposed in China to mean a Beijing-based spoken vernacular, a new usage whose model was probably the Japanese neologism kokugo (Kaske 2008, 135; Ramsey 1991, 37, 44). Putonghua, or "common speech," is a term that also originated under Japanese influence in the early 1900 s and came into official use in the People's Republic of China in the mid-1950s to describe the standard Chinese spoken language (Kaske 2008, 213-14). Huayu, or "Chinese (in the cultural sense) language" is a term used mainly in Singapore to refer to Mandarin (Duanmu 2007, 4; Norman 1988, 136-38). In any case, guoyu, putonghua, or huayu all point to the national standard language that was created between the $1910 \mathrm{~s}$ and the 1930s to serve a new national society.

The creation of a national standard language was inseparable from the conceptualization of regional forms of speech as "dialects": nonstandard and less prestigious (Tam 2016a). One could easily classify Chinese as a family of related but separate languages, since many of the "dialects" of China are so different from one another as to be mutually unintelligible-mutual intelligibility being the usual criterion for a language. Nonetheless, the terminology of language and dialect continues to be in use, as linguist and sinologist Jerry Norman (1988, 1-3) has written, because of longstanding cultural habit, a position also articulated by S. Robert Ramsey (1987, 16-18). Such a habit highlights how the distinction between a language and a dialect is largely based on political considerations. A unitary classificatory scheme such as the one used for China-in which there is but one Chinese language, albeit with many dialects-is an assertion of national and cultural unity (Moser 2016, 64-65; Norman 1988, 1-3). Statements to the contrary, therefore, have sensitive political implications about China as a cultural and political whole.

Alert to these political sensitivities, linguist and sinologist Victor Mair has argued that English-speaking scholars should more neutrally represent the way the Chinese themselves describe their own language situation. Objecting to the term "dialect," he has created an equivalent for the Chinese word fangyan by coining the Greek-derived neologism "topolect," or "speech of a place," which he finds more felicitous than John DeFrancis's etymologically mixed coinage "regionalect" (DeFrancis 1984, 57; Mair 1991, 7). What is clear to Mair and others is that, regardless whether "fangyan" or "topolect" is used to describe regional speech varieties in China, such a concept nowadays is almost always used to contrast them with China's standard language. Mair calls the standard "Modern Standard Mandarin," objecting to the lack of specificity in the term "Chinese." However, his terminological precision seems not yet to have caught on, at least in the literature on China: two fairly recent linguistics publications still use the terms "Standard Chinese" (Duanmu 2007) and "Modern Standard Chinese" (P. Chen $1999)$ to refer to China's standard language.

W. South Coblin $(2000,549)$ has argued that modern standard Mandarin is a "direct descendent" of the late nineteenth-century guanhua, the name of the transregional language used by officials and other educated people during the Ming (1368-1644) and Qing (1644-1911) dynasties. Some people have also equated guanhua with Beijing dialect, given that Beijing has been China's capital, with only brief interruptions, ever since the Yongle Emperor established that city as the capital in 1421. Susan Naquin $(2000,359)$, in her magisterial work on imperial Beijing, has said that the city's "local language" became guanhua, the imperial "administrative vernacular" starting in the fifteenth 
century, and that this language became the "national language" in the twentieth century. Benjamin Elman's (2000, 373-74) monumental work on the civil examination system asserts that "Peking alone" was the source of the language of officials in the Qing dynasty, an assertion he repeats in more recent work: "Beijing during the Qing dynasty provided the standard language for officials" (Elman 2013, 48). Coblin (2000, 549), as well as historian Elisabeth Kaske $(2008,41)$, have criticized this view, pointing out that guanhua was in fact more of a supraregional koiné than a strictly codified language of a people or a place. ${ }^{1}$ Moreover, until the mid-nineteenth century, guanhua was more strongly influenced by the dialect of Nanjing than by that of Beijing, the latter of which remained relatively unprestigious until the late nineteenth century (Chao 1976, 2; P. Chen 1999, 11; Coblin 2000, 537-43; 2007; Hirata 2000, 537-38; Kaske 2008, 66-74; Wilkinson 2015, 25; Yang 1989, 232).

While today's Mandarin is of course related in a significant way to these historical antecedents, it is a mistake to think of the modern national standard language as simply "descended" from them. Rather, Mandarin represents a conscious break with prior practice. The guanhua of the Ming and Qing dynasties was not only phonologically different from the modern language, it was also not codified and not used in the same way. Guanhua, though closely related to the written language of a substantial body of popular literature (Shang 2002, 4), was not an official form of writing-Classical Chinese served that purpose-and the modern language demanded a new level of phonological specificity, codified for the first time in phonetic scripts and audio recordings.

In sum, the creation of Mandarin represented a break with both the past and the present, not simply because of differences in linguistic content from its historical antecedents and other contemporaneous speech forms, but also especially because of the vastly different attitudes and practices associated with it. Sociologically speaking, the guanhua of the Ming and Qing dynasties was a language of convenience for a very narrow class of people needing to communicate across regional boundaries; the local speech of Beijing-which varied by neighborhood and social class-was the vernacular of a particular place. In contrast, Mandarin, as the newly codified standard spoken language of a newly constituted Chinese nation-state, was a uniform standard meant for all social classes and for all places in the nation. The creation of Mandarin, therefore, was predicated on the hope of creating a new kind of society.

\section{Inventing a New Kind of Language}

\section{The Legacy of May Fourth}

The dominant paradigm of language change in republican China is rooted in the narratives produced by intellectuals associated with the May Fourth movement, a set of intersecting ideological trends in which many of China's new intelligentsia were caught up in the 1920s and 1930s. In recent years, these narratives have come under renewed

\footnotetext{
${ }^{1}$ Koiné is a Greek word meaning "common" or "vulgar" and is a reference to the Greek term he koinè diálektos, or "the common language," one that combined elements of the speech of several different Greek regions and saw use as a lingua franca in the Hellenistic and Roman world. The word is now used to describe analogous language practices in other times and places.
} 
scrutiny. Considerable criticism has been leveled at May Fourth intellectuals for how they legitimized their ideological positions regarding language. To be sure, these intellectuals' scholarly shortcomings are numerous, but those shortcomings do not detract from the innovations that the May Fourth movement introduced in its approach to language. In short, in this section I argue that May Fourth claims about language reform are more productively read as prescription-normative statements about language-rather than description.

The May Fourth movement was named for the protests that took place in Beijing on and around May 4, 1919, against what people perceived to be the government's failure to uphold Chinese sovereignty at the Versailles treaty talks at the end of World War I. In venues such as the influential journal Xin Qingnian (New Youth), intellectuals associated with the movement advocated a shift from Classical Chinese to the vernacular, from a "dead" language to a "living" one, and from a language that was divorced from the speech and everyday lives of ordinary people to one that actually reflected their experiences. The "vernacular" in this narrative is usually cast as the "natural" language of the people, the written form that most closely resembles ordinary speech, and one that is easier to learn and thus helps spread literacy.

$\mathrm{Hu} \mathrm{Shi}$, one of the foremost proponents of language reform, repeatedly argued that the vernacular was the "living" language of the people. In perhaps his most famous essay, published in 1917 in New Youth and entitled "Wenxue Gailiang Chuyi" (A Modest Proposal for the Reform of Literature), he argued for a "living literature" (huo wenxue) to replace the "dead literature" (si wenxue) that followed classical models, arguing that China's language situation needed to undergo the revitalization that the Renaissance provided for European vernaculars ( $\mathrm{Hu} 1917,35)$. More than three decades later, he continued to stand fast by the vernacular he had spent his life so vigorously promoting, arguing for the indispensability of "the living spoken language written in characters" (Hu 1951, 898).

This tripartite formulation- "living," "spoken," and "written in characters"-neatly sums up Hu's position in the complex debates about language and literature in China in the first half of the twentieth century. The "living" language meant baihua, which he and other May Fourth intellectuals defined as the language of vernacular narrative fiction, such as the fourteenth-century novel The Water Margin and the mid-eighteenthcentury novel Dream of the Red Chamber, which $\mathrm{Hu}$ and his colleagues canonized and equated with the vernacular literature of Europe ( $\mathrm{Hu}$ 1917, 35). In addition to written baihua, Hu's description of it as "spoken" echoed the phonocentric perspective prevalent in Euro-American linguistics, in which the true substance of a language lay primarily in its sounds; writing was merely the visual representation of those sounds. While such an analytical perspective seems to be a description of language, in its transmission to Asia it became a prescription for language: that sound should be congruent with script, unlike Classical Chinese, a written language vastly different from everyday speech. Finally, in saying "written in characters," Hu was taking a relatively conservative position in the multifaceted debates on Chinese script reform, in which there were numerous proposals in the late nineteenth and early twentieth centuries to replace characters with easier-tolearn phonetic scripts (Cheng 2001; Kaske 2008, 93; Tsu 2010, 21-32).

In the last decade or so, much ink has been spilled in critiquing the factitiousness of May Fourth claims about history, language, and literature. The discussion of these claims 
has largely built on the consensus in the literature on nationalism that all assertions of "peoplehood" or "nationhood" are constructed from selective renderings of an imagined common history and of an invented national culture. For instance, historian Elisabeth Kaske, in her learned work The Politics of Language in Chinese Education, 18951919, traces the origins of the "literary revolution" (wenxue geming) of $\mathrm{Hu} \mathrm{Shi}$ and Chen Duxiu, and she argues that the May Fourth perspective still adheres to the notion of a series of intersecting "movements" - a "national language movement" (guoyu yundong) and a "vernacular literature movement" (baihua yundong)— that are too teleological. Instead, following the periodization of Li Jinxi (1934, part 1, 10), she begins her account with China's defeat in the First Sino-Japanese War in 1895 and argues that the broad outlines of language change in China follow the Latin-to-vernacular shift in Europe - a decline of diglossic language practices that is also integral to Hu Shi's reading of China's situation (Kaske 2008, xii). Literary scholar Shang Wei $(2002,2014$ ) has critiqued the factual basis of May Fourth intellectuals' historical and linguistic justifications for their reformist advocacy regarding China's language practices. After all, the Renaissance saw not only an increase in vernacular publications, but also a classicist return to Ciceronian standards of Latin composition and the rebirth of scholarship in Greek (Leonhardt 2013, 184-97). Finding the arguments of May Fourth intellectuals both simplistic and highly selective, Shang argues that they greatly exaggerated the dichotomy of baihua and wenyan; the two forms of written Chinese had coexisted for many centuries, and their use had never been quite as separate as the May Fourth ideologists claimed. Shang argues that, in fact, May Fourth language and literary reformers were simply replacing one form of elite language with another (Shang 2002, 5; 2014, 257).

These and other flaws of the various May Fourth justifications for their advocacy are quite real. But I argue that what also deserves scrutiny is the May Fourth vision for what Chinese language practices should be. Language reformers, of which May Fourth intellectuals formed a large part, wanted a stronger China, and they saw widespread literacy and education as a critical source of strength. In his 1934 history of language reform, Li Jinxi noted the widespread belief among Chinese intellectuals, in the aftermath of defeat in 1895, that Japanese strength emanated from its literate populace, that the "early opening up of its people's intellectual abilities" (min zhi zao kai) was the result of "widespread literacy" (renren neng dushu shizi) (J. Li 1934, part 1, 10). Chief among the concerns of modernizing intellectuals was the spread ( $p u j i)$ of education among the people. Qian Xuantong argued that education could not be spread without a "revolution" in characters, by which he meant alphabetization (hanzi bu geming, ze jiaoyu jue bu neng puji) (Qian 1923, 7). Countless government documents cited the spread of education as a crucial goal. The National Association for Education's (Quanguo Jiaoyu Hui) 1917 resolution for the use of zhuyin fuhao, a phonetic notation for the pronunciation of Chinese characters, cited a "desire to spread education" (yu mou jiaoyu puji) (SHAC 2010b, 16:769). In a 1922 report on the status of language education, the Ministry of Education cited the difficulty of learning Chinese characters as an impediment to "spreading education" (puji jiaoyu) (SHAC 2010a, 332). The language of literature, education, and the state, therefore, needed to become a tool for educating all people rather than just for a literate elite. This vision for what language could and should be was justified by appeals to historical continuity and plebeian authenticity, but in reality, as Shang 
(2014, 261) has argued, May Fourth language reformers "did not exactly do what they said they were doing or were expected to do." That is, the language they held up as a new standard was not the "people's" language, because the "vernacular" (guoyu and baihua) was in fact the language of an educated and cosmopolitan minority. Furthermore, the May Fourth excision of the vernacular from wenyan, their catch-all term for Classical Chinese, was more a rhetorical device and political posture than an argument rooted in historical fact.

As historical description, therefore, the May Fourth arguments about language crumble under scholarly reexamination. What I wish to point out, however, is that May Fourth claims about language can be read in an equally interesting way as prescription. That the actions of language reformers were new and historically discontinuous is in itself noteworthy. Language reformers sought to create a unified national language. In order to do so, they leaned heavily on the "raw materials" of existing language practices: a newly designated canon of vernacular literature; the northern Chinese dialects, particularly the form of guanhua based on Beijing dialect; and the stock of Chinese characters commonly used to write that literature and to notate those northern dialects. What emerged from their efforts was not in itself altogether new, but the slight modifications to existing language practices and the intensive efforts to disseminate those new practices constituted a novel orientation to language: a belief that language must be forged into a standardized totality and then wielded by the state as a tool to unite the people of a nation.

Mandarin, therefore, represents not merely a new language, but a new kind of language altogether. Classical Chinese was resolutely not a language of the people, for it functioned in a society in which popular literacy was not seen as an imperative. Language reformers in China, in contrast, sought a nationalized society in which literacy was universal, and using the "language of the people" was one of the practical ways to bring that about.

\section{Sources of the New National Standard}

The impact of the May Fourth movement on the state's orientation to language is evident even today. In 1956, only a few years after the Chinese Communist Party firmly established itself on the Chinese mainland, Zhou Enlai issued a now oft-cited statement on behalf of the State Council defining what the basis of the national language was to be:

汉语统一的基础已经存在了, 这就是以北京语音为标准音、以北方话为基础方言、以典范的现 代白话文著作为语法规范的普通话。

The basis for unifying Chinese (hanyu) already exists; that is, taking the pronunciation (yuyin) of Beijing as the standard pronunciation; taking the northern dialects as the base dialect; and taking the classics of modern vernacular (baihuawen) literature as the grammatical norm of the common language (putonghua). (Zhou Enlai 1956)

Apart from the use of putonghua instead of guoyu as the name of the national standard language, there is nothing in this definition that $\mathrm{Hu}$ Shi-no supporter of the Communist Party himself — would have found objectionable. The putonghua of mainland China today 
mainly differs in minor respects from the guoyu of Taiwan: some character readings have been adjusted to reflect even more closely Beijing pronunciation, and the vocabulary used in each region has diverged somewhat in the years since the GMD retreated to Taiwan in 1949. Indeed, this mainland Chinese description of the basis for a national language is all the more surprising given that it represents a position that many Chinese leftists would have rejected through most of the republican period. For them, such a single national language would not have been close enough to the diverse forms of the everyday speech of the masses.

Noted linguist and sinologist John DeFrancis (1950, 211-20) echoed the leftist position in his earlier writings, advocating that people be allowed to write their own local dialects in phonetic scripts, a situation he called linguistic "federalism," as opposed to linguistic "integralism," a much more centralized approach to state language policy that he accused the GMD of espousing. DeFrancis's position on language and nationalism was a bold one to take for an American academic amid the fearful anti-communism of the 1950s, and his arguments provoked at least two liberal émigrés to criticize his views not only for aligning with the communists, but also for being highly impracticable $\mathrm{CHu}$ 1951; Michael 1951). Nevertheless, DeFrancis held to this position for the next few decades, excoriating the communist regime for reversing its original position and adopting essentially its predecessor's linguistic integralism (DeFrancis 1984, 257-87).

These republican-era policies were explicitly aimed at national integration, and they represented an intensification of the state's efforts at regulating the language practices of the people it ruled. Explicit attempts at linguistic regulation go at least as far back as the Yongzheng reign (1722-35), when the emperor, exasperated by the unintelligible speech of officials from Fujian and Guangdong, ordered that they and their successors learn guanhua at specially created institutions (Paderni 1988, 258). Efforts to spread knowledge of guanhua also were found in late Qing educational reforms, although the dynasty collapsed before these came to fruition. It was mainly after the beginning of the republican period in 1911 that language reform really took off. While the course of reform was charted by a few intellectuals at the political center of the nascent and unstable Chinese republic, the spread of these reforms was repeatedly stymied by the political fragmentation of the period and then by renewed Japanese aggression beginning in 1937. Nonetheless, the shape that language reform policies took in this politically unstable yet socially innovative period in Chinese history eventually formed the basis of the hegemonic language practices we can observe in contemporary China. These policies centered on the design of a new language that could be used in common by all citizens of the Chinese nation, regardless of social class-a state of affairs that represented a stark departure from the highly stratified language situation in imperial times. As I will show, the design of the sounds of Mandarin wended a tortuous path through the 1910s, 1920s, and 1930s, but the process nonetheless reflected the purpose of the language's designers: to create a new language for a new society in which the official language was more accessible than before.

One of the most familiar and recognizable features of Mandarin today is its reliance on the phonology (or pronunciation) of Beijing dialect. Nothing might seem more natural than to base the language of a nation on the speech of its capital. Indeed, as one of the principal developers of pinyin, Zhou Youguang (1906-2017), has written, "Taking Beijing pronunciation as the standard for Putonghua is the historical result of the more than 1000 
years that Beijing has been the capital of the Liao, Jin, Yuan, Ming, and Qing dynasties and the following regimes" (Zhou Youguang 1986, 8). As a broad generalization about Chinese capital cities, Zhou's statement is mostly true, but it does ignore the times in which Beijing's status as capital was interrupted, most notably at the beginning of the Ming dynasty between the years 1368 and 1421, and also during the middle of the republican period, when the GMD moved the nation's capital to Nanjing for the decade between 1928 and 1937. What is more problematic about this statement, however, is that the connection between Beijing's longstanding historical status as China's capital and the use of its dialect as the basis of the national language is a post hoc justification of nationalist language policies. In fact, at the start of the republican period, the pronunciation of the national language underwent considerable debate, with many factions opposing the use of Beijing dialect as a phonological basis. Such opposition was rooted in a variety of factors. To begin with, the study of Chinese phonology traditionally did not depend on the pronunciation associated with any one particular location. For centuries, the phonological information supplied in lexicons and rhyming dictionaries did not dictate exactly the way a character was supposed to sound, but rather the degrees of similarity between abstract categories of character rhymes. These categories might not have reflected the rhymes in any particular living dialect in China, but they were nonetheless important in the composition of rhyming poetry. The exact readings or vocalizations of characters were not considered important, at least for the composition of Classical Chinese texts, whose vocal realizations were ancillary to their use as written documents (P. Chen 1999, 12).

Because of this orientation to phonology, the earliest documentation of how any particular dialect was pronounced comes from sources foreign to China (Coblin 2007). In the fifteenth century, we find hangŭl guides to the pronunciation of guanhua compiled for use by Korean diplomats to the Ming court. In the sixteenth, seventeenth, and eighteenth centuries, Catholic missionaries to China compiled more guides to guanhua. And in the nineteenth century, Christian missionaries began documenting the various dialects of the regions in which they proselytized. It was also in the nineteenth century that the European diplomatic presence in China required language pedagogy for communication with the Chinese imperial court, and it was then that such landmark works as British diplomat Thomas Francis Wade's (1818-95) lexicon of Beijing dialect appeared. Published in 1859, Wade's work introduced the earliest version of what was to become the Wade-Giles transcription system (Wade 1859).

Based on the alphabetical transcriptions in these foreign sources, it is possible to deduce the evolution of the phonology of guanhua, one of the main linguistic sources for today's Mandarin. From the Ming dynasty until the middle of the nineteenth century, the sources display a heavy bias towards Nanjing pronunciation, which presumably was due to Nanjing's status as the Ming dynasty's initial capital and, even after the court's removal to Beijing, the city's status as a major cultural center in China. Additionally, Nanjing pronunciation (as well as southern guanhua and southern dialects in general) was phonologically richer than its northern counterparts, and thus it conformed more closely with the abstract rhyming standards found in the rhyming dictionaries of the period, which documented the phonologically richer speech patterns of the past. In fact, Wade's mid-nineteenth-century lexicon was initially criticized by other linguists because of its reliance on Beijing dialect to provide readings for Chinese characters. The 
pronunciation of Nanjing only began to lose ground in the second half of the nineteenth century, probably because of the gradually increasing cultural clout of Beijing. The Taiping Rebellion (1850-64), a major sectarian civil war that threatened Qing rule and contributed to the destruction and depopulation of Nanjing, the rebel capital, certainly did not help (Coblin 2000, 541; Coblin and Barrett 1997, 536).

In spite of these developments, Beijing's place in China's array of linguistic practices was still not secure even into the 1910s and 1920s, when the standardization of phonology by the new republican Ministry of Education was just beginning. Many anti-Qing nationalists associated Beijing-based guanhua with the Qing regime that had collapsed in 1911, and thus opposed any standard based on it (Kaske 2008, 336, 367). Moreover, language reformers, steeped in classical Chinese phonology, mostly felt Beijing dialect to be a poor reservoir of sounds from which to draw, because it was among the most phonologically impoverished of China's regional dialects, and thus not very euphonious in the poetic sense. Yuen Ren Chao (1892-1982), the famed Chinese linguist, composer, musician, and all-around polymath, recalled later in life that the speech of Beijing did not hold any special part in his early education, and that his family's Changzhou dialect was more useful in learning traditional Chinese phonology (Chao 1976, 6). But what the national standard language should sound like remained a difficult question to resolve. The difficulty stemmed from the political conundrums that surfaced in the aftermath of the Qing collapse in 1911, when proponents of a new form of political association and organization-nationalist in ideology and republican in aspiration-sought to replace the Qing institutions that had grown over the centuries to oversee a vast multiethnic empire. These imperial institutions exercised varying forms of governance, and which one of those forms depended on the many constituencies that the Qing emperorship had to address. How to replace this segmented imperial polity with a unitary nationstate, one which now occupies essentially the same territory and which rules over an equally heterogeneous population, is one of the foundational political dilemmas that all of the Qing dynasty's successor regimes have had to face (Crossley 2000, 341, 361).

Language reformers in China had to take into account this heterogeneity, which was considerable even within the majority Han population. ${ }^{2}$ They did this in two main stages. In the first stage, language reformers attempted in the 1910s to create an ecumenical standard, one that incorporated the features of several different major dialects. This process was contentious, and in the beginning it was not at all settled what the new national language would sound like. Some intellectuals, such as the onetime anarchist and later staunch GMD member Wu Zhihui (1865-1953), were Esperanto enthusiasts who envisioned a modernized China in which the Chinese language, which they viewed as archaic and cumbersome, would be replaced with Esperanto (Ramsey 1987, 3; Tsu 2010, 63). In the end, however, holders of such radical ideas were unable to gain enough leverage to legitimize and implement their views (Kaske 2008, 207).

The initial standard of the 1910s originated with the Committee for the Unification of Reading Pronunciations (Duyin Tongyi Hui), which met in Beijing under the auspices of the Ministry of Education under the republican government in Beijing at the time. ${ }^{3}$

\footnotetext{
${ }^{2}$ Curiously, other non-Han languages were not considered.

${ }^{3}$ The term "reading pronunciation" refers to the fact that, until the first two decades of the twentieth century, literary pronunciations of Chinese characters, which represented an elevated register,
} 
About eighty delegates were invited, two from each Chinese province, and one additional representative each for the Mongolian and Tibetan ethnicities, as well as one representative for overseas Chinese. Forty-four of these delegates met in Beijing in February 1913, and their principal aim was to standardize the pronunciations of Chinese characters. Relying on a Qing-era rhyming dictionary, Yinyun Chanwei (The Subtleties of Phonology) by Li Guangdi (1642-1718), the delegates produced standardized pronunciations for 6,500 characters. These pronunciations were notated in a new phonetic script, principally developed by Wu Zhihui, called zhuyin zimu (sound-annotation characters). This script consisted of thirty-nine alphabetic symbols, essentially simplified portions of Chinese characters, and it followed traditional Chinese phonology by dividing each character's pronunciation into three possible parts: an initial, a medial, and a final.

About 90 percent of the character pronunciations at this conference were derived from Beijing guanhua, while elements of other dialects were also included, particularly the $\mathrm{Wu}$ family of dialects of the eastern provinces of Jiangsu and Zhejiang, where many of the delegates were from. For example, to Beijing's four tones the standard added an additional fifth tone, the rusheng or "entering tone," which was present in some southern dialects in the form of syllables ending in $-p,-t$, and $-k$. This fifth tone was conceived for the national language as a sort of glottal stop, though its precise phonological realization was never fully explained, and it was ultimately eliminated in the early 1930s. The results of this initial standardization, an "abstract conglomeration of elements from phonologies across the country" meant to represent the whole of the Chinese nation (Tam 2016b, 78), were published in the Guoyin Zidian (Dictionary of National Pronunciation) in 1919 (P. Chen 1999, 16-19; Kaske 2008, 406-15; Li Jinxi 1934, 50-66; Ramsey 1987, 3-18; Zhang 1938, 336).

While hardly a complete language reform, the steps taken by the members of the Duyin Tongyi Hui represented a major step towards the standardization of Chinese phonology. They attempted to bridge the gap in practices among northern and southern Mandarin speakers by creating a standard that would be acceptable and somewhat familiar to as many people as possible. For instance, sometime in the 1920s, Duyin Tongyi Hui member Qian Xuantong wrote to his committee colleague Wu Zhihui debating the merits of keeping the -ong and - eng rhyming classes of character rhymes separate, as was usual in northern Chinese practice, as opposed to Wu's original proposal that they be merged, as southerners were used to doing (thus causing characters like 東 dong and 夢 meng to rhyme). Qian argued that the rhyming classes, which were merged in the Dictionary of National Pronunciation, should be separated as they were in northern dialects. In his letter, Qian indicated these rhymes using zhuyin zimu, to illustrate his point:

然先生去年之底、曾說過、南人不善讀國音之L、所以還是留下々 $\times$ 等、負得他們讀

『篷、蒙』為『朋、孟』。此南音之朋孟 然玄同以為此法似無用處。因國音中之音、南音不 習慣者不止此一處。

were distinguished from ordinary pronunciations in everyday speech. The characters with reading pronunciations that differed from ordinary pronunciations, however, constituted only a small fraction of the lexicon (Børdahl 1992, 31-32; Shang 2014, 279, 289-90). 
我因聽明北方之庚東確是一開一合、所以衝定庚確是 $L$ 、東確是 $L+X 介$ 介音而為 $\times L$ 。 為此辦法、與北音實毫無牽強之處。所以主持將國音字典上注々 $\times$ 文 $\times L \overline{\overline{\Pi \times L}}$

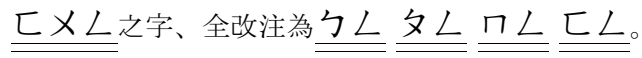

As you said at the end of last year, southerners are not good at the eng in National Pronunciation, so it would be best to keep [rhymes like] bong, etc. allowing them to read “篷 [péng], 蒙 [měng]” [in the same way] as “朋 [péng], 孟 [mèng].” This is because in the national pronunciation, the things that not found in southern pronunciation are not limited to this point....

Because I clearly hear the northern [pronunciations of] 庚 [gēng] [and] 東 [dōng] as open and closed respectively, therefore it is clear that [the rhyme of] 庚 is eng, and 東 is eng + the medial vowel $u$, yielding ong. According to this analysis, the connection with northern pronunciation is hardly implausible. Therefore I suggest, for the Dictionary of National Pronunciation, that the characters glossed as bong, pong, mong, fong be re-glossed as beng, peng, meng, feng. (Qian, n.d.) ${ }^{4}$

Ultimately, Qian's view was the one that prevailed, and in today's Mandarin, the -ong final cannot appear after the initials $b, p$, or $m$; these initials can only be followed by the -eng final.

Another instance of language reformers' attempts to reflect multiple regional pronunciations in the standard language was recorded in the diary of Yuen Ren Chao. On Saturday, September 18, 1920, Chao wrote-in English-about a meeting with other members of the Preparatory Committee for the Unification of the National Language (Guoyu Tongyi Choubei Weiyuanhui):

Riksha to Board of Education \& went to 國語統一籌備會 [Guoyu Tongyi Choubei $\mathrm{Hui}]$ with 3 rooms. Few arrived. Then came 黎 $[\mathrm{Li}$, i.e., the linguist Li Jinxi 黎錦 熙, 1890-1978] \& 汪 [Wang, the linguist Wang Yi 汪怡, 1875-1960]. I spent most of morning discussing International English German French experiment etc. equivalents \& other questions with 汪. 錢玄同 [Qian Xuantong] came later. Lunched there with 汪 etc. Continued discussion till late 6 . Worked practically a continuously whole day with satisfactory results. We decided to make 万 unaspirated $\mathrm{v}$ but recommend $\mathrm{w}$ so that 万 will

\section{衣烏迂}

become obsolete. ${ }^{5}$ We decided to use i $\mathrm{u}$ y both as vowels \& as initials y w \& French hu (comme en huit). We decided to use au for $\varkappa^{6} \&$ not ou. This was

\footnotetext{
${ }^{4}$ All translations are my own.

${ }^{5}$ The symbol 万 was one of the original zhuyin zimu that was used to represent the voiced initial $v$, which is present in the Wu family of dialects of eastern China, which for instance includes Shanghainese. It was in the reading of such characters as 窩, read as vo in the initial standard, but now read as wo. It indeed became obsolete by the late 1920s.

${ }^{6}$ The zhuyin equivalent of ao in pinyin.
} 
mostly my motion. Use ou for 歐, 後, 狗, [ōu, hòu, gǒu] etc. instead of eu or əu. We argue I explained my principle of time-pitch curves to describe tones. But they did ne I had no opinion of my own which of the kinds of actual tones we should use for the 3 or 4 tones. After long discussions, we decided tentatively to write out 3 standards, 北京, 南京, \& 四川 [Beijing, Nanjing, \& Sichuan]. I was delegated to write on the description of the actual tones. Most of the regular workers in the 教育部 [Jiaoyu bu, Ministry of Education] went home, but we non-salary drawers talked \& talked till after 6. (Chao 1920)

In this entry, we can see how the committee members attempted to account for dialectal differences in their discussions about standardization-Chao notes that they were going to work out the pronunciations of three regions that spoke related and somewhat mutually intelligible dialects: Beijing, Nanjing, and Sichuan.

This attempt at creating an ecumenical standard ultimately failed, however. In the later 1920s, Chao and his colleagues, including Liu Fu (later courtesy name Liu Bannong, 1891-1934), Lin Yutang (1895-1976), Wang Yi, and Qian Xuantong, gradually coalesced into a subgroup of the Preparatory Committee for the Unification of the National Language. They nicknamed themselves the Shurenhui, or "Society of a Few Men," and in the course of their discussions they decided that the artificial standard, which became known as "Old National Pronunciation" (lao guoyin), was too difficult to disseminate, since no skilled speakers existed to teach this artificially constructed language, possibly only with the exception of Chao himself. In the end, these men decided to try to bring the national pronunciation fully into line with "the natural speech of Peking city" (Chao et al. 1977, 78). Such an effort, however, encountered stiff opposition at first. All through the 1910s and 1920s, debates among language reformers raged between those who supported the initial 1913 standard (which they called guoyin, or the "national pronunciation") and those who supported Beijing pronunciation (known as jingyin). For instance, in 1921, a representative of the Jiangsu Association for National Language Research (Jiangsu Guoyu Yanjiu Hui) sent a letter to Wu Zhihui expressing how "baffled and flabbergasted" (qiguai chayi) he was at a proposal put forward at the seventh annual meeting of the National Federation of Education Associations (Quanguo Jiaoyu Hui Lianhe Hui). The proposal in question moved to adopt the pronunciation of Beijing as the national standard. To the perplexed writer, the question of a phonological standard had already been settled in favor of "national pronunciation" at an earlier meeting in May of the Preparatory Committee for the Unification of the National Language, at which many experts in phonology had been consulted (Jiangsu Association for National Language Research 1921).

In spite of the opposition, by the late 1920s, the debate had died down and settled on the Beijing position (Simmons 2017, 79-82). In 1932, the Ministry published the first pronouncing glossary of characters in this revised pronunciation, Guoyin Changyong Zihui (Glossary of Commonly Used Characters in the National Pronunciation), thus indicating that the "national pronunciation" (guoyin) had shifted decisively in favor of Beijing

${ }^{7}$ The name Shurenhui was a reference to the Qieyun, a rhyming dictionary compiled by Lu Fayan in $601 \mathrm{CE}$, whose preface said, "We few men decide, and it is decided" (wo bei shu ren, ding ze ding yi) (Chao et al. 1977, 78). 
pronunciation. This phonological standard subsequently became known as "new national pronunciation" (xin guoyin), and in this dictionary, pronunciations were indicated in the original zhuyin zimu, which were renamed zhuyin fuhao, or "sound-annotating symbols" to emphasize that they could not stand alone, thus reassuring those who supported the continued use of Chinese characters that they would not be abolished in favor of an alphabetic script. ${ }^{8}$ Pronunciations were also notated in the National Romanization system (Guoyu Luomazi) — in which tones on the same syllables were "spelled out" using different spellings-that Chao himself invented. Thus at a stroke, as Chao claims, a million native-speaking teachers were created, since the standard reflected the speech of educated natives of Beijing (Chao et al. 1977, 77-78). Chao may have oversimplified, however: even the prefatory material for this dictionary noted that not all the sounds of Beijing dialect were accepted into the new standard. As Wu Zhihui wrote in one of the prefatory chapters:

其於第一原則, 則指定北平地方為國音之標準; 所謂標準, 乃取其現代之音系, 而非字字必遵其

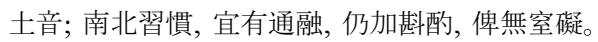

The first principle [in this glossary] is to set the area of Beiping [Beijing] as the standard for the national pronunciation; by what is called standard, I mean its modern phonology (yinxi), but this does not mean that every character necessarily follows the local pronunciation (tuyin); in the custom of North and South, it is proper that there should be flexibility among the two, and thus in considering this we have sought to remove hindrances [in communication]. (Wu 1933, iii)

So even in the move towards bringing the standard in line with Beijing pronunciations, the people involved-Chao, $\mathrm{Wu}$, and others—sought to distinguish standard Mandarin from Beijing dialect in order to bridge regional differences. In essence, language reformers from the 1910s to the 1930s were attempting to create a language that reflected the actual practice of a variety of regions of the newly conceived Chinese nation-state. Of course, this nation-state was more imagined than real in this time period, as successive, putatively central governments in Beijing and then Nanjing attempted to exert control over regions of the country that had fallen under warlord rule. Ultimately, these reformers moved to a more regionally specific standard with their adoption of most of Beijing pronunciation in Mandarin, but they still sought to keep the standard separate from any dialect.

\section{A New Language for a New Kind of Society}

Thus far, I have discussed Mandarin largely as an idealized code designed by a few dedicated intellectuals. But for whom was this code designed, and by whom was this new language meant to be learned? Mandarin, an "invention" meant "to capture that which united all of China's people” (Tam 2016b, 282), was motivated by nationalistic aims - a unified language for a modern Chinese nation, just as other modern nations of the world were seen by Chinese intellectuals to have unified national standard languages.

${ }^{8}$ The zhuyin fuhao (also known as bopomofo) are still used in primary schools in Taiwan today in Mandarin-language pedagogy. 
While language reform made headway primarily in the creation of the standard amid the political turmoil of the 1910s and 1920s, the spread of this standard was made easier after the relative consolidation of power under the Nationalist regime during the Nanjing Decade (1928-37), when Chiang Kai-shek (1887-1975) designated Nanjing as the national capital. One publication by the Chinese National Language Educational Association (Guoyu Jiaoyu Cujin Hui), the Guoyu Yuebao (National Language Monthly), from 1927 illustrates the nationalist aims of the promoters of Mandarin:

統一的國家, 應該有統一的精神。統一的精神, 從那 [ sic ] 裡來呢? 在於人民思想、感情的溝通 和團結。全國人民的思想感情, 怎麼會溝通和團結呢？在於由統一的語言和言文一致的文字。

A unified (tongyi) country should have a unified (tongyi) spirit. Where, then, does a unified spirit exist? It exists in the connections and unity (tuanjie) among the thinking and feelings of the people. How do the thinking and feelings of the people of the whole country become connected and united (tuanjie)? The solution lies in a unified speech (yuyan) and a script (wenzi) that reflects speech (yanwen yizhi). (Guoyu Yuebao 1927, 5)

This and other such publications shows how the Chinese state intended to create a unified speech community out of the linguistically disparate parts of a Chinese nation. The members of this newly constituted nation, "Our Republic of China," consisted of the five main ethnic groups recognized in republican times: "the Han, Manchu, Mongolians, Hui, and Tibetans," although Mandarin itself was essentially a Han language; the languages of the other ethnicities, it seems, received hardly any attention (Guoyu Yuebao 1927, 5).

The education ministry's efforts were not limited to such propaganda. Indeed, it heavily intervened in the textbook publishing industry, indicating its approval of various textbooks all through the republican period-approval that had a crucial effect on the ability of such publishers as the Commercial Press to sell textbooks to schools (Culp 2008; Reed 2004, 205-11). Additionally, in conjunction with local municipal education bureaus (jiaoyu ju), the ministry also held mobile schools (liudong xuexiao) and fairs to promote the use of Mandarin, at least among schoolteachers. The Wu Zhihui Papers at Stanford contain the record of at least four such fairs in the Jiangnan region in 1930: two in Shanghai and two in Nanjing, at which Mandarin educational publications were exhibited and primary and secondary school teachers were tested and graded in their language ability (Chinese National Language Educational Association 1930a, 1930b, 1930c, 1930d).

The publication of Mandarin magazines, the holding of Mandarin fairs and educational events, along with government intervention in textbook publishing to create Mandarin textbooks - these efforts coincided with the gradual spread of Mandarin-language media into everyday life. In recent presentations on work in progress, historian Janet Y. Chen $(2013 \mathrm{~b}, 2015)$ has painted a picture of a world in the 1920s and 1930s in which the new technologies of visual and aural recordings and broadcast media began to penetrate into the lives of ordinary people, who often encountered Mandarin as almost a foreign and alien language. That ordinary people were now considered a necessary constituency 
of a state-sponsored official language was a significant break with the past, when only a select group of literate elites were involved with the official language.

All these developments indicate that the national language, because it was new and unknown to most of the population, represented an as yet unmet obligation: the people who should learn Mandarin were members of the Chinese nation, however one might construe or imagine such a nation. The effort, then, to create a speech community that was congruent with the intended political-territorial community was an integral part of language reform, and it has continued to create tensions over those who contest the state's unitary vision of what it means to be a member of the nation: recent tensions over such issues as Mandarin education in Xinjiang and Mandarin broadcasting in Guangdong highlight the conflictual nature of the practical efforts to linguistically constitute a Chinese nation (Apple Daily 2010; Jacobs 2014; Tam 2016b, 276-91).

\section{Conclusion}

In many ways, the creation, dissemination, and current ascendancy of Mandarin as a language of all Chinese people is a reflection of a new ideal for organizing society: a unified national speech community in which the standard language is accessible to all and mastery of which is based on individual ability rather than class background. Before language reform, the official language was restricted to a narrow stratum of classically educated literati; perhaps only 10 percent of the population in Ming and Qing times had access to the Classical Chinese literacy that would have allowed access to the civil examination system, the main path to social advancement. Meritocracy-the advancement of individuals based on native ability and personal effort-was largely restricted to the "fully classically literate gentry-merchant elites" (Elman 2013, 132-33). ${ }^{9}$ Afterwards, however, the whole nation was supposed to be held to the same linguistic standard, with more opportunity for advancement. Of course, this was the intention and the ideology, but whether such a meritocratic ideal has worked out in practice in any country is, I concede, very much open to question.

The expansion of such meritocratic thinking and practice in the realm of language practices is a reflection of a nationalist modernity in which linguistic universalism transcended localities but stopped at the nation's borders. In such a world, it becomes possible to view language standards as tools of bourgeois hegemony and oppression rather than as a means to liberation, a common mindset in social theory and sociolinguistics in the past few decades. That is, such a hegemony occurs (in the Gramscian sense) when people, even those whose ability to use the standard is limited, subscribe to "standard language ideology" (Milroy 2001): they become complicit in their own oppression. Hence the putative dispute between prescriptive and descriptive linguistics, which is

\footnotetext{
${ }^{9}$ The term "meritocracy" - meaning intelligence plus effort—was coined (as a pejorative) by British Labor Party activist Michael Young. The word first appeared in his 1958 novel The Rise of the Meritocracy, which was a satire in the vein of Brave New World. It portrayed a stark future in which meritocracy led to ever-increasing inequality and a sense of entitlement among the meritocratically privileged (Young 1958). Of course, defining what constitutes "merit" has always been contentious and often reflects the values of those in power (Karabel 2005, 5; Subramanian 2015).
} 
almost always resolved in favor of the latter. In a linguistically modern world, in which all members of a society are held to an explicitly defined set of rules for a standard language, all people in theory then have an opportunity to participate in educational and economic meritocracy. Linguistic descriptivism, as it has often been used in sociolinguistics, can only take place in a world in which standard language ideology is largely taken for granted, and in which the standard language has already heavily influenced most people's language practices and perceptions. That is, one cannot decry the punctiliousness of prescriptivism in a world in which there are no standard languages in the modern (often nationalist) sense. In premodern times, official languages were unavailable to the bulk of humanity, when supraregional classical languages were used by a small class of elites in many parts of the world. Now, standard languages are supposed to be available to everyone, a state of affairs dismissed as "the illusion of linguistic communism" (Bourdieu 1991, 43).

In this paper, I have sought to historicize an instance of linguistic modernity by charting the rise of a national standard language in China. In so doing, I seek in part to counter the simplistic opposition to standard languages as tools of oppression that is sometimes found within the descriptivist literature. I am not attempting to dispute the roles of standard languages and standard language ideology in perpetuating class privilege and existing forms of social stratification. Many sociolinguistic studies have demonstrated such a phenomenon. Nevertheless, I seek to remind readers that there was a time before nationalist language standardization, in which opportunity for advancement through education was limited to a far narrower subset of the human population. When compared with such a world, the national unification of languages, even with all its attendant problems and oppressions, represents a significant advance.

\section{Acknowledgments}

The research for this paper was supported in part by a National Science Foundation Doctoral Dissertation Research Improvement Grant (SES-1603086). I thank John Lie, Wen-hsin Yeh, Mara Loveman, and Pamela Crossley for insightful comments. Thanks also to Jeffrey Wasserstrom and five anonymous reviewers for help with substantial improvements to this paper. An earlier version of this paper was presented on the panel "Language Standardization and State Power in the Twentieth-Century Sinosphere" at the conference Language, Power and Identity in Asia: Creating and Crossing Language Boundaries, organized by the International Institute of Asian Studies, Leiden University, March 15, 2016. I am grateful to my co-panelists, Gina Tam, Thomas Mullaney, and Rachel Leow, for sharing their research and allowing me an opportunity to present. A subsequent version of this paper was presented in an Anthropology Department Colloquium at Nanjing University on June 8, 2016. I am grateful to Professor Fan Ke for that invitation, and for incisive questions and comments from the faculty and students who were present. I would also like to thank the members of the 2015-16 UC Berkeley Institute of East Asian Studies Haas Junior Scholars Program for Doctoral Candidates for productive discussions about my research: Kira Donnell, Sujin Eom, Grace Kim, James Lin, Ti Ngo, Gustavo Oliveira, Dongmin Park, and Kristen Sun. The Haas program's conference at UC Berkeley in October 2016, East Asia as Method, provided a further presentation opportunity; I thank our discussant Laura Nelson for incisive comments. Finally, I must thank Cathy Weng for help with reading some of the primary 
sources. All errors are solely my own. Correspondence should be addressed to jeffrey. weng@berkeley.edu.

\section{List of References}

Apple Daily (Hong Kong). 2010. "Guangzhou Wanren Shangjie Zhang Guangzhouhua: Fangbaojing Jiebei; Bianyijing Toupai; 80 Hou Dingyingshang” 廣州萬人上街撐廣州 話：防暴警戒備；便衣警偷拍；80後頂硬上 [Guangzhou Crowd of 10,000 March in Support of Cantonese: Riot Squad Mobilized; Undercover Agents Snoop for Evidence; Post-80s Generation Out in Numbers]. July 26. http:/hk.apple.nextmedia. com/news/art/20100726/14277814 (accessed April 15, 2018).

Børdahl, Vibeke. 1992. "Wen Bai Yi Du: Literary and Colloquial Forms in Yangzhou Storytelling." CHINOPERL 16(1):29-63.

Bourdieu, Pierre. 1991. Language and Symbolic Power. Cambridge, Mass.: Harvard University Press.

Chao, Yuen Ren. 1920. “Notebook for September 11 to October 7, 1920.” Yuen Ren Chao Papers, BANC MSS 83/30 c Carton 35. Bancroft Library, University of California, Berkeley.

1976. "My Linguistic Autobiography." In Aspects of Chinese Sociolinguistics: Essays, 1-20. Language Science and National Development. Stanford, Calif.: Stanford University Press.

Chao, Yuen Ren, Rosemary Levenson, Laurence A. Schneider, and Mary R. Haas. 1977. "Yuen Ren Chao: Chinese Linguist, Phonologist, Composer and Author." BANC MSS 78/43. Bancroft Library, University of California, Berkeley. http://digitalassets.lib.berkeley.edu/rohoia/ucb/text/chineselinguistph00chaorich.pdf (accessed April 15, 2018).

Chen, Janet Y. 2013a. "Dueling Sounds, Contending Tones: The Pronunciation Wars of the 1920s in China." Council on East Asian Studies, Yale University. http:// ceas.yale.edu/events/dueling-sounds-contending-tones-pronunciation-wars-1920schina (accessed April 15, 2018).

— . 2013b. "Voices of a New Nation: Learning to Speak 'Mandarin' in China, 1928 1937." Presented at the Association for Asian Studies Annual Conference, San Diego. http://www.asian-studies.org/Portals/55/Conference/Archives\%20Page/2013 \%20program\%20merged.pdf?ver=2018-04-17-150237-333 (accessed May 8, 2018). . 2015. "Encounters with the 'National Language' from Colony to Nation: Taiwan, 1935-1955." Presented at the Association for Asian Studies Annual Conference, Chicago. http://tinyurl.com/ksy72ft (accessed April 15, 2018).

Chen, Ping. 1999. Modern Chinese: History and Sociolinguistics. New York: Cambridge University Press.

Cheng, W. K. 2001. "Enlightenment and Unity: Language Reformism in Late Qing China." Modern Asian Studies 35(2):469-93. doi:10.1017/S0026749X01002074.

Chinese National Language Educational Association. 1930a. "Nanjing Guoyu Liudong Zhanlanhui Baogaoshu” 南京國語流動展覽會報告書 [Report on the Nanjing National Language Traveling Fair]. Zhongguo Guomindang Records, ZHI Reel 57, File ID 0315. Hoover Institution Library and Archives, Stanford University, Stanford, Calif.

. 1930b. “Nanjing Guoyu Liudong Xuexiao Yijie Xingqi Guoyuke Baogaoshu” 南京國 語流動學校一屆星期國語科報告書 [Report on the Nanjing National Language Traveling School First Weekly Mandarin Course]. Zhongguo Guomindang Records, ZHI Reel 
57, File ID 0317. Hoover Institution Library and Archives, Stanford University, Stanford, Calif.

. 1930c. “Shanghai Guoyu Liudong Zhanlanhui Baogaoshu” 上海國語流動展覽會報告書

[Report on the Shanghai National Language Traveling Fair]. Zhongguo Guomindang Records, ZHI Reel 57, File ID 0318. Hoover Institution Library and Archives, Stanford University, Stanford, Calif.

- 1930d. “Shanghai Guoyu Liudong Xuexiao Yijie Xingqi Guoyuke Baogaoshu”上海國 語流動學校一屆星期國語科報告書 [Report on the Shanghai National Language Traveling School First Weekly Mandarin Course]. Zhongguo Guomindang Records, ZHI Reel 57, File ID 0316. Hoover Institution Library and Archives, Stanford University, Stanford, Calif.

Coblin, W. South. 2000. “A Brief History of Mandarin.” Journal of the American Oriental Society 120(4):537-52.

— 2007. Modern Chinese Phonology from Gūanhuà to Mandarin. Paris: École des Hautes Études en Sciences Sociales, Centre de Recherches Linguistiques sur l'Asie Orientale.

Coblin, W. South, and T. H. Barrett. 1997. "Notes and Communications: Palatalization of Velars in the Nanking Dialect." Bulletin of the School of Oriental and African Studies, University of London 60(3):533-40.

Crossley, Pamela Kyle. 2000. A Translucent Mirror: History and Identity in Qing Imperial Ideology. Berkeley: University of California Press.

Culp, Robert. 2008. "Teaching Baihua: Textbook Publishing and the Production of Vernacular Language and a New Literary Canon in Early Twentieth-Century China." Twentieth-Century China 34(1):4-41. doi:10.1353/tcc.0.0011.

DeFrancis, John. 1950. Nationalism and Language Reform in China. Princeton, N.J.: Princeton University Press.

1984. The Chinese Language: Fact and Fantasy. Honolulu: University of Hawai'i Press.

—. 1989. Visible Speech: The Diverse Oneness of Writing Systems. University of Hawai'i Press.

Duanmu, SAn. 2007. The Phonology of Standard Chinese. 2nd ed. Oxford: Oxford University Press.

Elliott, MаRк C. 2001. The Manchu Way: The Eight Banners and Ethnic Identity in Late Imperial China. Stanford, Calif.: Stanford University Press.

. 2006. "Ethnicity in the Eight Qing Banners." In Empire at the Margins: Culture, Ethnicity, and Frontier in Early Modern China, eds. Pamela Kyle Crossley, Helen F. Siu, and Donald S. Sutton, 27-57. Berkeley: University of California Press.

Elman, Benjamin A. 2000. A Cultural History of Civil Examinations in Late Imperial China. Berkeley: University of California Press.

2013. Civil Examinations and Meritocracy in Late Imperial China. Cambridge, Mass.: Harvard University Press.

Fishman, Joshua A. 1972. Language and Nationalism: Two Integrative Essays. Rowley, Mass.: Newbury House Publishers.

Gunn, Edward M. 1991. Rewriting Chinese: Style and Innovation in Twentieth-Century Chinese Prose. Stanford, Calif.: Stanford University Press.

Guoyu Yuebao 國語月報 [National Language Monthly]. 1927. “Quanguo Guoyu Jiaoyu Cujin Hui Mujuan Qi” 全國國語教育促進會募捐啟 [A Call for Donations for the Committee for the Promotion of National Language Education]. September 1. Wu 
Zhihui Papers, Zhongguo Guomindang Records, ZHI Reel 57, File ID 03021. Hoover Institution Library and Archives, Stanford University, Stanford, Calif.

Haeri, Niloofar. 1997. "The Reproduction of Symbolic Capital: Language, State, and Class in Egypt.” Current Anthropology 38(5):795-816. doi:10.1086/ca.1997.38. issue-5.

Hasan, Ruqaiya. 1999. “The Disempowerment Game: Bourdieu and Language in Literacy." Linguistics and Education 10(1):25-87. doi:10.1016/S0898-5898(99)80104-1.

HiRATA SHŌJI 平田昌司. 2000. “Qingdai Honglusi Zhengyinkao” 清代鸿䶻寺正音考 [An Investigation into the Correct Pronunciation of the Qing Honglusi]. Zhongguo Yuwen 中国语文 6:537-44.

Hu SHI. 1917. “Wenxue Gailiang Chuyi” 文學改良忽議 [A Modest Proposal for the Reform of Literature]. Xin Qingnian 新青年 2(5):26-36.

—. 1951. "Review of Nationalism and Language Reform in China. By John De Francis." American Historical Review 56(4):897-99.

Jacobs, Andrew. 2014. “A Devotion to Language Proves Risky.” New York Times, May 11. http://www.nytimes.com/2014/05/12/world/asia/a-devotion-to-language-proves-risky. html (accessed April 15, 2018).

Jiangsu Association for National Language Research, Jiangsu Guoyu Yanjiuhui 江蘇國 語研究會. 1921. “Jiangsu Guoyu Yanjiuhui Fandui Yi Beijingyin Wei Biaozhunyin” 江 蘇國語研究會反對以京音為標準音 [The Jiangsu Association for National Language Research Opposes the Use of Beijing Pronunciation as the National Standard]. Zhongguo Guomindang Records, ZHI Reel 56, File ID 2924. The Hoover Institution Library and Archives, Stanford University, Stanford, Calif.

Karabel, Jerome. 2005. The Chosen: The Hidden History of Admission and Exclusion at Harvard, Yale, and Princeton. Boston: Houghton Mifflin.

Kaske, Elisabeth. 2008. The Politics of Language in Chinese Education, 1895-1919. Boston: Brill.

Labov, William. 1966. The Social Stratification of English in New York City. Washington, D.C.: Center for Applied Linguistics.

1972. Language in the Inner City: Studies in the Black English Vernacular. Conduct and Communication no. 3. Philadelphia: University of Pennsylvania Press.

Leonhardt, Jürgen. 2013. Latin: Story of a World Language. Translated by Kenneth Kronenberg. Cambridge, Mass.: Harvard University Press.

Li, Chris Wen-Chao. 2004. "Conflicting Notions of Language Purity: The Interplay of Archaising, Ethnographic, Reformist, Elitist and Xenophobic Purism in the Perception of Standard Chinese." Language and Communication 24(2):97-133. doi:10.1016/j.langcom.2003.09.002.

. 2014. "Shifting Patterns of Chinese Diglossia: Why the Dialects May Be Headed for Extinction." In Divided Languages? Diglossia, Translation and the Rise of Modernity in Japan, China, and the Slavic World, eds. Judit Árokay, Jadranka Gvozdanović, and Darja Miyajima, 65-86. Transcultural Research - Heidelberg Studies on Asia and Europe in a Global Context. Cham: Springer International Publishing. doi:10.1007/978-3-319-03521-5_5.

LI JINXI 黎錦熙. 1934. Guoyu Yundong Shigang 國語運動史綱 [Outline of the National Language Movement]. Shanghai: Shangwu Yinshuguan.

Lippi-Green, Rosina. 1997. English with an Accent: Language, Ideology, and Discrimination in the United States. London: Routledge.

LiU, Jin. 2016. "A Historical Review of the Discourse of Fangyan in Modern China." Twentieth-Century China 41(3):217-33. doi:10.1080/15215385.2016.1205788. 
Liu, Lydia. 1995. Translingual Practice: Literature, National Culture, and Translated Modernity-China, 1900-1937. Stanford, Calif.: Stanford University Press.

. 2004. Clash of Empires: The Invention of China in Modern World Making. Cambridge, Mass.: Harvard University Press.

Mair, Victor H. 1991. "What Is a Chinese 'Dialect/Topolect'? Reflections on Some Key Sino-English Linguistic Terms.” Sino-Platonic Papers 29.

Michael, Franz. 1951. "Review of Review of Nationalism and Language Reform in China, by John De Francis." American Political Science Review 45(3):890-92. doi:10.2307/1951181.

Milroy, James. 2001. "Language Ideologies and the Consequences of Standardization." Journal of Sociolinguistics 5(4):530-55.

— 2012. Authority in Language: Investigating Standard English. Routledge Linguistics Classics. New York: Routledge.

Moser, David. 2016. A Billion Voices: China’s Search for a Common Language. Scorsby, Victoria, Australia: Penguin.

Naquin, Susan. 2000. Peking: Temples and City Life, 1400-1900. Berkeley: University of California Press.

Norman, Jerry. 1988. Chinese. New York: Cambridge University Press.

Oxford English Dictionary. 2000. “Mandarin, n.1.” OED Online. Oxford University Press.

Paderni, Paola. 1988. "The Problem of Kuan-Hua in Eighteenth Century China: The Yung-Cheng Decree for Fukien and Kwantung." Annali (Istituto Universitario Orientale, Napoli) 48(4):257-65.

Peng, Chun-YI. 2016. “Talk Shows and Language Attitudes: A Sociolinguistic Investigation of Language Attitudes towards Taiwan Mandarin among Chinese Mainlanders." Presented at Language, Power and Identity in Asia: Creating and Crossing Language Boundaries, Leiden.

Qian Xuantong 錢玄同. n.d. “Letter from Qian Xuantong to Wu Zhihui." February 22 (no year). Zhongguo Guomindang Records, ZHI Reel 109, File ID 9976. The Hoover Institution Library and Archives, Stanford University, Stanford, Calif.

—. 1923. “Hanzi Geming!” 漢字革命 ! [A Revolution in Chinese Characters!]. Guoyu Yuekan 國語月刊.

Ramsey, S. Robert. 1987. The Languages of China. 2nd ed. Princeton, N.J.: Princeton University Press.

— 1991. "The Polysemy of the Term Kokugo." Sino-Platonic Papers 27:37-47.

Reed, Christopher A. 2004. Gutenberg in Shanghai: Chinese Print Capitalism, 18761937. Vancouver: University of British Columbia Press.

Sanders, Robert M. 1987. "The Four Languages of 'Mandarin."” Edited by Victor H. Mair. Sino-Platonic Papers 4.

SHaC (Second Historical Archives of China, Zhongguo Di’er Lishi Dang’anguan) 中國第二歷史檔案館. 2010a. Beiyang Zhengfu Dang'an 北洋政府檔案 [Archives of the Beiyang Government]. Beijing: Zhongguo Dang'an Chubanshe.

. 2010b. Zhonghua Minguo Shi Dang’an Ziliao Huibian Zongmu Suoyin 中華民國史檔 案資料匯編總目索引 [Indexed Contents of Historical Archival Materials of the Republic of China]. Vol. 16. Nanjing: Fenghuang Chubanshe.

Shang WeI. 2002. "Baihua, Guanhua, Fangyan and the May Fourth Reading of Rulin Waishi.” Edited by Victor H. Mair. Sino-Platonic Papers 117. 
— 2014. "Writing and Speech: Rethinking the Issues of Vernaculars in Early Modern China.” In Rethinking East Asian Languages, Vernaculars, and Literacies, 1000 1919, ed. Benjamin A. Elman, 254-301. Boston: Brill.

Shin, Shu-MeI. 2011. "The Concept of the Sinophone." PMLA 126(3):709-18. doi:10.1632/pmla.2011.126.3.709.

Simmons, Richard VanNess. 2017. "Whence Came Mandarin? Qīng Guānhuà, the Bĕijīng Dialect, and the National Language Standard in Early Republican China." Journal of the American Oriental Society 137(1):63-88.

Subramanian, Ajantha. 2015. "Making Merit: The Indian Institutes of Technology and the Social Life of Caste." Comparative Studies in Society and History 57(2):291322. doi:10.1017/S0010417515000043.

Tam, Gina Anne. 2016a. “'Orbiting the Core': Politics and the Meaning of Dialect in Chinese Linguistics, 1927-1957.” Twentieth-Century China 41(3):280-303. doi:10.1353/tcc.2016.0021.

2016b. "Sounding the Nation: Dialect and the Making of Modern China." PhD diss., Stanford University.

Tsu, Jing. 2010. Sound and Script in Chinese Diaspora. Cambridge, Mass.: Harvard University Press.

Wade, Thomas Francis. 1859. The Hsin Chin Lu, or, Book of Experiments: Being the First of a Series of Contributions to the Study of Chinese. Hong Kong: Printed at the office of the "China Mail."

Wilkinson, Endymion. 2015. Chinese History: A New Manual, Fourth Edition. Cambridge, Mass.: Harvard University Asia Center.

Wu Zhinur. 1933. “Fu Benhui Qing Gongbu ‘Guoyin Changyong Zihui’ Han” 附本會請公 布《國音常用字彙》函 [Letter in Support of the Promulgation of the Glossary of Commonly Used Words]. In Guoyin Changyong Zihui 國音常用字彙 [Glossary of Characters in Common Use in the National Pronunciation], ed. Jiaoyubu Guoyu Tongyi Choubei Weiyuanhui 教育部國語統一籌備委員會 [Committee for the Unification of the National Language of the Ministry of Education], i-x. 3rd ed. Shanghai: Shangwu Yinshuguan.

Yang, Paul Fu-mien. 1989. "The Portuguese-Chinese Dictionary of Matteo Ricci: A Historical and Linguistic Introduction.” In Zhongyang Yanjiuyuan Di 2 Jie Guoji Hanxue Huiyi Lunwenji, Yuyan Yu Wenzi Zu [Proceedings of the Second International Conference on Sinology, Academia Sinica, Section on Linguistics and Paleography], 2:1:191-242. Taipei: Academia Sinica.

Young, Michael Dunlop. 1958. The Rise of the Meritocracy, 1870-2033: An Essay on Education and Equality. London: Thames and Hudson.

Zhang Shilu 張世祿. 1938. Zhongguo Yinyunxue Shi 中國音韻學史 [A History of Chinese Phonology]. 1st ed. Zhongguo Wen Hua Shi Cong Shu, Di 2 Ji. Changsha: Commercial Press.

Zhou EnLai. 1956. “Guowuyuan Guanyu Tuiguang Putonghua de Zhishi” 国务院关于推广 普通话的指示 [State Council Guidance on Promoting Putonghua]. http://www.gov.cn/ test/2005-08/02/content_19132.htm (accessed April 15, 2018).

Zhou, Gang. 2011. Placing the Modern Chinese Vernacular in Transnational Literature. New York: Palgrave Macmillan.

Zhou Youguang. 1986. "Modernization of the Chinese Language.” International Journal of the Sociology of Language 59:7-24. 